\title{
МУЗИЧНИЙ КЕРІВНИК ДОШКІЛЬНОГО НАВЧАЛЬНОГО ЗАКЛАДУ НОВОӤ ФОРМАЦІї: ТЕХНОЛОГІЧНИЙ АСПЕКТ
}

Шуть М. М. Музичний керівник дошкільного навчального закладу нової формації: технологічний аспект.

У статті зроблено спробу систематизації професійних вимог до сучасного музичного керівника дошкільного навчально-виховного закладу та обгрунтовується перелік сучасних фахових компетенцій.

Ключові слова: музичний керівник, професійні вимоги, компетентність.

Шуть М. М. Музыкальный руководитель дошкольного образовательного учреждения новой формации: технологический аспект.

В статье сделана попытка систематизации профессиональных требований к современному музыкальному руководителю дошкольного учреждения и составлен перечень современных специальных компетенций.

Ключевые слова: музыкальный руководитель, профессиональные требования, компетентность.

Shut M. M. Music teacher in preschool of new formation: technological aspects.

In the article the professional requirements to modern music teacher in preschool educational establishment are systematized and the list of modern professional competencies is justified.

Key words: music teacher, professional requirements, competence.

Динаміка науково-технічного й інформативно-технологічного прогресу, значущість інтеграційних процесів і глобальних соціальних і культурних трансформацій, з якими зіткнулося сучасне суспільство, вимагають переосмислення пріоритетів підготовки фахівців дошкільної освіти. Переорієнтація сприяє пошуку науковцями і практиками нових ефективних важелів формування адаптованої до сучасних запитів суспільства, спрямованої на високі гуманістичні цінності, стимулюваної перетворювальним вектором особистості вихователя.

Одним із природних i високоефективних напрямів розвитку творчої особистості дошкільника є музичне мистецтво, яке в поєднанні з іншими видами мистецтва на основі гри інтегрує духовні сили дитини в їхній активності, необхідній для життєтворчості. Мета cmammi - систематизувати професійні вимоги до сучасного музичного керівника дошкільного виховного закладу.

Питання підготовки фахівців для системи дошкільної освіти вивчали Л. Артемова, А. Богуш, Н. Гавриш, Л. Загородня, В. Кузь, М. Машовець, Т. Поніманська, С. Попиченко, О. Юдіна й решта. Сутність підготовки педагога-музиканта, шляхи формування і зміст таких розкрито у працях Я. Бурлаки, С. Нечай, Г. Падалки, О. Радинової, Т. Танько й інших. Стрижневим висновком наукових праць $є$ переконання, що система підготовки фахівців-музикантів для сучасного дошкільного закладу має орієнтуватися на особливості музичного мистецтва як виду діяльності.

Художньо-музична діяльність $є$ синкретичним творчим процесом, який відповідає віковим, психофізіологічним та етико-естетичним потребам дошкільників, гарантує інтенсивність емоційно-почуттєвих сил дитини, уможливлює розвиток комплексу музичних здібностей, збуджує «творчий інстинкт», забезпечує поліваріантність вибору засобів здійснення продуктивної діяльності. Оперування дитини у просторі музичного мистецтва неможливе поза логіко-інтелектуальною, художньо-емоційною та дійовопрактичною роботою.

Під час повноцінної музичної діяльності формуються основи музичної і художньої культури дітей, набуваються види творчого пізнання дійсності, оптимізуються особистісні якості, виробляється здатність оцінювати явища дійсності, естетичний смак, що розширює 
можливості насолоджуватися красою i створювати ii, розширюються асоціативні уявлення, збагачуються світовідчуття, завдяки систематичному розвитку органів почуттів забезпечується сенсорний, емоційний та інтелектуальний розвиток дітей. Залучення дитини до музичної діяльності та інтегрованих музикою інших видів мистецтв оптимізує загальну творчу активність, акумулює перетворювальну енергію, які, завдяки реалізації творчих здібностей, неодмінно відіб'ються в сьогоденній та в майбутній предметній творчій діяльності. У цілому накопичений дитиною у музичній діяльності досвід набуває в онтогенезі особливо ціннісного статусу. Аналогічних надбань під час занурення до сфери музичної діяльності набуває і дитина і доросла людина.

Забезпечує реалізацію усіх вище перерахованих завдань музичного виховання у дошкільному закладі спеціальний фахівець - музичний керівник, який має першим коректно і системно ввести дитину до світу прекрасного, доброго, творчого, емоційно високого, і закріпити ці позитиви як ціннісні.

Незважаючи на те, що музичне мистецтво супроводжує людину майже з перших кроків онтогенезу людини, а організація музичного виховання юних громадян має давню і гідну історію, професія «музичний керівник дошкільного навчального закладу» є зовсім новою.

Відповідно до прийнятої постанови Ради народних комісарів України «Про заходи в справі поширення мережі і поліпшення роботи дитячих садків Української РСР» (березень 1944 р), відомства та органи народної освіти окреслили важливі питання, спрямовані на всебічний розвиток особистості, важливим складником якої $\epsilon$ музично-естетичне виховання. 3 цією метою Радою Міністрів було затвердження наказ «Про введення в типові штати дитячих садків посади музичного керівника», а у відповідних інструкціях Міністерства освіти було надано пропозиції щодо організації роботи музичних працівників, виділення коштів на їх оплату, покращення змісту музичного виховання дітей, удосконалення організації і змісту методичної роботи, розроблення нових іiі форм (методичні об'єднання музичних працівників, теоретичні семінари та семінарипрактикуми, педагогічні виставки, гуртки, педагогічні читання, конференції, університети педагогічних знань, школи передового педагогічного досвіду тощо), метою яких було підвищення педагогічної кваліфікації музичних вихователів шляхом оволодіння кращим досвідом роботи, вдосконалення методів і прийомів виховної роботи та розвитку художнього смаку дітей, надання методичної допомоги молодим вихователям у галузі вокально-музичного і хореографічного мистецтва тощо.

Дещо різні назви професії «музичний керівник» у певні історичні часи характеризували різні підходи до фахової спрямованості. «Музичний працівник» здебільшого виконував просвітницько-розважальні функції (фрагментарний педагогічний вплив, епізодичне прикрашання музикою життя дітей у дитсадку), а «музичний вихователь» переважно займався питаннями системного музичного виховання (виховання інтересу й любові до музики, розвиток музикальності, формування певної вправності у різновидах музичної діяльності, виховання основ художнього смаку тощо). У понятті «музичний керівник» синтезувалися всі позитиви попередніх понять і акцентовано увагу на керівній та плановоорганізаційній функції фахівця.

Сучасний «музичний керівник» - професія на рідкість багатогранна, в якій інтегруються низка видів діяльностей і синкретично поєднуються:

- універсальний музикант-виконавець (інструменталіст (часто володіє більш ніж одним музичним інструментом), вокаліст, диригент);

- вихователь (педагог 3 навчання основам співів, хореографії, грі на дитячих i шумових музичних інструментах, ігромайстер, методист, просвітницький і громадський діяч, агітатор тощо);

- технолог навчально-виховного процесу (системний менеджер освіти: проектувальник, керівник навчально-виховних процесів, дослідник, експериментатор, фахівець з моніторингу музичних здібностей, модератор творчої групи (дітей, колег, батьків), розробник наочності тощо); 
- творець (інтерпретатор змісту програми $з$ дошкільної освіти, автор і вдосконалювач методик, імпровізатор, винахідник інструментів, сценарист, режисер, постановник, а ще поет, композитор, актор, хореограф, імітатор);

- спеціаліст сфери дозвілля (сценограф, акомпаніатор, звукорежисер, декоратор, ляльковод, шоумен, культуролог тощо);

- спеціаліст з технічних засобів (магнітофон, електрофон, аудіоплейєр, електромузичний інструмент, оператор ПК тощо).

«Музичний керівник» має бути підготовленим і до діяльності ще в низці професій (спеціальностей), а саме: костюмер, розробник і виробник атрибутів, бібліотекар (в тому числі Інтернет-матеріалів) тощо.

Наведений перелік дозволяє впевнитись в унікальності, надзвичайній складності професії «музичний керівник ДНЗ» і визначній відповідальності такого за наслідки виховання дітей (зважаючи на особливу сензитивність представників дошкільного віку до занять музично-естетичною діяльністю та значущість результатів розвитку етикоемоційної сфери в онтогенезі людини).

Викладене переконує в необхідності конструктивного перегляду ставлення відповідних ланок суспільства і влади в цілому до професії «музичний керівник ДНЗ» 3 метою

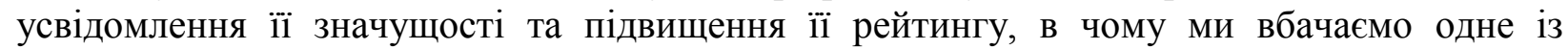
потенціальних джерел зростання ефективності дошкільної освіти зокрема і загальної освіти в цілому.

Виходячи 3 викладеного, спроба розглядати сучасне музичне виховання дитини дошкільного віку тільки як допомогу їй у процесах пізнання духовної спадщини рідної культури з надбанням такої у видах музичної діяльності виглядає дещо звужено. Поперше, музичне мистецтво, як унікальний ресурс концентрованого людського й емоційнодуховного досвіду, як унікальні мова спілкування та поле для діяльності і творчості наполягає на розширенні культурологічної компоненти духовної спадщини рідної культури гідними зразками світової культури. Сучасна дитина $є$ i дитиною нації, i дитиною світу.

По-друге, потрібно визначитися 3 провідними видами музичної діяльності. Традиційним для дошкільної освіти є розуміння під такими: слухання музики, спів, гра на музичних інструментах, музично-ритмічні рухи, музично-хореографічні постановки, танці, вправи, різновиди музичних ігор, види імпровізації, драматизацію тощо. Такий підхід суперечить природі побутування музичного мистецтва, що ставало предметом низки досліджень науковців (Б. Асаф'єв, О. Ростовський, Л. Школяр, Б. Яворський та інші).

Виходячи $з$ положень теорії музичного мистецтва, за якими матерією музичного твору $\epsilon$ емоційно-інтонаційне вираження адаптивно-креативних дій композитора (накопичення, перетворення вражень та особистісних переживань в оригінальну комбінацію звуків), яке фіксується умовними спеціальними символами (нотами, позначеннями) і простягається у просторі та часі завдяки інтерпретаційно-виконавській діяльності демонстратора (перетворення нотного тексту на звуковий) і сприймається суб'єктом як певна емоційнодуховна субстанція, основу музики складають три взаємодетермінованих види діяльності: композиторська, виконавська і музичне сприймання. Отже, є доцільним і коректним уважати провідними видами музичної діяльності саме композиторську, виконавську і музичне сприймання. Тоді слухання музики, спів, музично-ритмічні рухи, гра на дитячих музичних інструментах та інші становлять форми й засоби долучення дітей до музичного мистецтва.

У провідних видах музичної діяльності розвивається базова особистісна якість сприйнятливість до музичної матерії і створюються умови для прищеплення здатностей «приймати», «передавати», «трансформувати» i «видозмінювати» музично-естетичний матеріал. 
Отже, сучасний музичний керівник має розглядати музичну практику дитини як систему складників: сприймання, виконавство, творчість (імітація, імпровізація). Музично-освітня діяльність набуває характеристики допоміжної, такої, що забезпечує процеси музичного виховання завдяки вербалізації. Загальний шлях до пізнання мистецтва має відбуватися за схемою: виховання емоційно-почуттєвої сфери - засвоєння елементарних знань - оволодіння уміннями та навичками - самореалізація дитини у творчій діяльності.

Діяльність сучасного музичного керівника ДНЗ скерована метою, завданнями і змістом Базового компоненту дошкільної освіти в Україні (сфера «Культура», субсфера «Світ мистецтва») та виходить із комплексу завдань музично-естетичного і загальнокультурного виховання дитини. Відповідно до вихідних завдань, ефективність роботи сучасного музичного керівника дошкільного навчального закладу забезпечується знанням:

- вимог законодавчих та нормативних документів 3 питань освіти (зокрема Базового компоненту дошкільної освіти в Україні);

- мети і задач гармонічного розвитку принципів створення здоров'язберігаючого i культуроформувального простору та доцільного розвивального музично-естетичного середовища в ДНЗ: (музичний зал, куточок у групі для музично-ігрової діяльності дітей, інформаційно-методичні стенди для вихователів і батьків, кабінет керівника);

- дитини у провідних видах та формах музичної діяльності в контексті генеральної програми або програм, що реалізуються в конкретному ДНЗ;

- сучасних технологій розвитку у дітей музикальності, емоційної сфери, музичних $\mathrm{i}$ творчих здібностей, про шляхи формування елементарних уявлень музичної культури, формування музичного смаку;

- мети, задач, змісту і форм організації музично-виховного освітнього процесу як чинників синергетичного впливу на дитину й механізмів реалізації цього процесу;

- принципів планування процесу музичного розвитку дитини у видах та формах музичної діяльності з урахуванням ï̈ вікових, психофізіологічних особливостей, нахилів, здібностей, інтересів, потреб;

- методів моніторингу і діагностування музичного й емоційного розвитку дитини у різновидах і формах музичної, сценічної, хореографічної діяльності.

Професіоналізм та компетентність сучасного музичного керівника ДНЗ виявляється в реалізованих уміннях:

- розробляти і впроваджувати процеси формування музично-освітнього процесу, в яких реалізуються ефективні методи розвитку дитини у видах і формах музичної діяльності;

- доцільно і коректно використовувати традиційний і сучасний музично-педагогічний інструментарій (умови і засоби реалізації системи музичного виховання, організація навчально-виховного процесу, фіксація результатів), що забезпечує ефективність музичного сприйняття i розвиток музикальності та враховує індивідуальні й вікові особливості дошкільників, рівень їх музичного і загального розвитку;

- самовдосконалюватись, прагнути підвищення фахової компетентності, поширення інтересів, збільшення об'єму, допоміжної і цікавої інформації;

- сприяти розвитку дитячої творчості і стимулювати вияви такої; надаючи дітям право реалізовувати власні прагнення, обирати суб'єктивні способи самовираження, добирати ефективні засоби імпровізації;

- упроваджувати у педагогічну діяльність інноваційні технології формування музичних здібностей та розвитку емоційної сфери вихованців;

- вивчати, узагальнювати та поширювати позитивний педагогічний досвід (власний або інших колег); 
- проводити семінари (практикуми, майстер-класи) для музичних керівників та консультації (складення комендацій) для вихователів з питань методики музичного виховання, в тому числі у дистанційному форматі;

- організувати діяльність у різновидах і формах музичної діяльності протягом дня (особливо другої частини його);

- організовувати дитячі свята і розваги за розробленими сценаріями, які б відповідали і віковим та психофізіологічним запитам, потребам й інтересам дітей, культурологічним і сценарно-режисерським вимогам;

- організовувати заходи за участю дітей, спеціалістів ДНЗ, педагогів і батьків (тематичні вечори, сімейні свята, клуби тощо);

- здійснювати музично-педагогічну освіту батьків у різних формах (консультації, клуби, круглі столи, семінари), в тому числі засобами наочної інформації, ПК-презентацій, INTERNET-технологій тощо;

- здійснювати взаємодію з професійними об'єднаннями та культурно-просвітніми організаціями району, міста.

Професійні вимоги до сучасного музичного керівника дошкільного навчальновиховного закладу мають трансформуватися відповідно до змін картини життя, сучасного розуміння теорії й практики музичного мистецтва, запитів суспільства й сучасних фахових вимог. Корекція посприяє пошуку науковцями і практиками нових ефективних важелів формування високотехнологічного музичного керівника.

\section{Література}

1. Коментар до Базового компонента дошкільної освіти в Україні : [наук.-метод. посіб.] / ред. О. Л.Кононко. - К. : Дошкільне виховання, 2003. - 168 с. 2. Програма виховання і навчання дітей дошкільного віку «Дитина». - К. : Богдана, - 2003. 387 с. 3. Танько Т. П. Музично-педагогічна компетентність майбутнього вихователя дошкільного навчального закладу. - Х. : Нове слово, 2003. - 248 c. 